Валерій ПАЦУНОВ

\title{
МЕТАФОРА ЯК ПЕРЛИНА ТЕАТРАЛЬНОГО МИСТЕЦТВА
}

Стаття належить до циклу статей «Алгоритм народження метафори», перша глава якої опублікована у Віснику № 20 КНУТКТ. Автор детально висвітлює прочес творення театральних метафор, алгоритм народження сиенічного образу, посилаючись на власний багаторічний режисерський досвід на прикладах вистав «Король вмирає» Е. Йонеска та «Собор Паризької Богоматері» за романом Віктора Гюго..

Стаття розрахована на дослідників театрального мистечтвва, викладачів та студентів творчих вишів, теоретиків та практиків театру, широкого кола прихильників сиени.

Ключові слова: театр абсурду (парадоксу), апокаліпсис, сиенографія.

Статья принадлежит к ииклу статей «Алгоритм рождения метафоры»», первая глава которой опубликована в Вестнике № 20 КНУТКТ. Автор детально освещает проиесс создания театральных метафор, алгоритм рождения сиенического образа, ссылаясь на собственный многолетний режиссерский опыт на примерах представлений «Король умирает» Е. Йонеско и «Собор Парижской Богоматери» за романом Виктора Гюго.

Статья рассчитана на исследователей театрального искусства, преподавателей и студентов творческих вузов, теоретиков и практиков театра, широкого круга поклонников сиены.

Ключевые слова: театр абсурда (парадокса), апокалипсис, сценография.

The article belongs to the cycle of articles "The algorithm of the birth of the metaphor», the first chapter of which is published in the Journal No. 20 of the Kyiv National I. K. Karpenko-Kary Theatre, Cinema and Television University.

Author reproduces in details the process of creating a theatrical metaphor, the algorithm of birth of a scenic image. The author is referring to his numerous years of experience of his on directing practice Production of the performances «The King dies» by E. Ionesco and «The Cathedral of Our Lady of Paris» based on Victor Hugo's novel.

This article is intended to the theatrical art teachers and researchers and art students, theater theoreticians and practitioners, a wide range of scenes fans.

Key words: theatre of absurdity (to the paradox), apocalypse, scenography.

Сучасна історія нашої держави оригінальна тим, що майже всі президенти незалежної України (а на час написання цих рядків спливає iï третє десятиліття) на фініші владної кар'єри зазнавали нищівної електоральної поразки, залишаючи по собі чергову політичну та економічну кризу. 3 огляду на це п'єса вождя абсурдизму Ежена Йонеска «Король вмирає» може слугувати нам 3 вами красномовною метафорою нежиттєздатності вітчизняних керманичів і не лише, до речі, часів Незалежності, а й радянських часів. Чи не тому вже понад століття ми плетемося у хвості цивілізації? А втім, будь-яка влада стоїть або на «торф'янику», що палко жадає спалахнути у будь-який час, або на болоті, що мріє іiї поглинути.

У Йонескf 3 кожним ударом королівського серця тріщать стіни його палацу, разом зі згасанням Короля 3 катастрофічною швидкістю зникають під водою ліси, поля, міста, державні установи, люди. 3 колись грандіозного королівства залишилися лише маленькі острівці та затонулі міністри. Але генієві абсурду й цього замало: загибель королівства він супроводжує катаклізмами Всесвіту - зіштовхує між собою Планети та знищує Галактики. Армагеддон! Блискучі літератур- 
ні, а водночас і кінематографічні метафори! Театрові нема чого тут робити.

Як це таке яскраве «кіно» переплавити в не менш яскраву (а бажано більш яскраву) сценічну метафору? Яким має стати сценографічний образ приреченості нікчемної влади? До речі, чи звернули ви увагу, дорогі мої читачі, на те, що сценічна метафора, як правило, проростає зі сценографії? 3 матеріального середовища, 3 костюма, 3 реквізиту, зі світла, з кінетики, з пластики. Під акомпанемент звуку.

I от кілька років п’єса лежала на полиці моєї шафи недоторканою - інтуїція моя спала, не дарувала мені ніяких адекватних темі картинок, яскравіших та багатших за авторські. Здавалось, що надто грандіозні планетарні метафори автора були непідйомними в умовах скромних матеріальних та просторових можливостей мого театру.

I от одного прекрасного дня в одному зі спортивних магазинів я наштовхнувся на надувний басейн діаметром 5 метрів, висотою $70 \mathrm{~cm}$. американського виробництва. Еврика! Держава на воді! Вона потопає! Всесвітній потоп!

Наливаємо 25 кубометрів теплої води, а в центрі цього «моря» ставимо на воду королівський трон! От тепер все зійшлось! До всесвітнього потопу (макрокосм) додаємо хиткість влади на воді (мікрокосм)!

I оцей рятівний Басейн диктує мені увесь подальший сценографічний набір: надувні крокодили, надувні леви, плавальне спорядження, ласти, вудочку, на яку виловлюють 3 «моря» тіла міністрів (голови, тулуби, руки та ноги дитячих ляльок-пупсів). А головне - королівський трон у вигляді великого надувного крісла-кенгуру. Неначе всі бутіки України та Болгарії (я й туди мотнув) змовились та викинули того літа в продаж конче необхідні для мого абсурду дотепні курортні аксесуари.

I, о, диво! Коли на першій водній репетиції Король приплив до трону-кенгуру і намагався його осідлати, в нього геть нічого не виходило трон вислизав 3-під нього! Актор нервував, лаявся, проклинав режисера, (він же - сценограф), басейн, кенгуру разом 3 крокодилами, згадував їхніх матерів, але все було марно - трон нахабно ігнорував свого хазяїна. А я у захваті верещав у залі: «Геніально! Це образ твоєї ідіотської влади! Продовжуй борсатись у боротьбі за трон!» Так, випадково, вмить загострилося відчуття хиткості влади. Будь-якої влади! Буквально! Фізично! Натуралістично!

Та чи випадково знайшлося це рятівне рішення? За законами діалектики ця випадковість була проявом закономірності, втіленням щойно народженої Конституції вистави, прописаної Диво-Басейном. I от тепер він, Басейн, став режисером та сценографом. А я лише покірно виконував його вказівки!

I коли, нарешті, розлючений актор долав цей слизький владний бар'єр та важко дихаючи, падав у його лоно знесиленим, наставала мить рідкісної для театру мистецько-філософської гармонії. I на сцені, і в глядачевій залі. Бо і ми, глядачі, спіймали й Смисл, і Нерв вистави. I Розумом, і Відчуттям. Щаслива мить! «Мить, зупинись, бо ти прекрасна!» - як сказав класик.

Однак це була лише половина справи. Бо хиткість влади $є$ лише локальним фактом цієї історії. А як ії глобалізувати? Якби збожеволіли б усі королі та президенти планети Земля, то чи не розкололася б наша куля? А слідом за нею чи не порушилася б гармонія Світу, фізика Космосу, на що і натякав Йонеско?

Сценічне рішення цієї філософської сентенції теж впало на мою голову цілком «несподівано»iii продиктував усе той же Басейн. Уявіть собі, друзі, що ви сидите в глядачевій залі. Як відомо, планшет сцени має висоту 80 см. Висота нашого басейну -70 см. Разом - півтора метри. То чи будете ви 3 вашого крісла бачити воду з крокодилами? Дзуськи! Все котові під хвіст!

Що ж робити? «Споруджувати наді мною овальне дзеркало!» - кричить мені Басейн. «П'ятиметрове у діаметрі!» - додає. I я слухняно виконую волю цього Диктатора, підвішую на троcax величезне дзеркало і отримую у його віддзеркаленні Двійника Басейну з усіма його водними пригодами. Слава Богу, море $з$ крокодилами та затонулими міністрами врятоване! Подальші дії диктує мені новонароджений Двійник. "Для полегшення монтажу ріж мене на вісім дольок!»волає. "Які своїми краями пролягають від периметру кола до його иентру!» - додає. Слухняно виконую його примхи та отримую легко керовану штанкетами восьмичастинну конструкцію дзеркала. I, вже не чекаючи підказок новоявленого Диктатора-Двійника, самостійно злітаю у Космос! Тепер з кожним ударом серця Короля дзеркальне небо над королівством буде розколюватись та тріщати, 3 кожним ударом грому здригатись та розхитуватись! Таким чином, у моїх руках опиняється дивовижний трансформер з безліччю образних перетворень - якщо підняти одночасно гострі вершини трикутних дольок, як пелюстки квітки, то отримуємо величезну корону; якщо ці гострі пелюстки опустити донизу, то одержимо гостро- 
зубі щелепи якогось страхітливого чудовиська. До того ж ці зуби можуть «дихати», розкриватись за закриватись, загрожуючи проковтнути все, що трапиться на їх шляху.

Фінал вистави - голову Короля, що стоїть по груди у воді (трон вже щез під хвилями всесвітнього потопу) покриває густий мокрий сніг (генератор мокрого снігу). Під «Космогонію» польського авангардиста Кшиштофа Пендерецького на сніжну голову Короля повільно опускаються з Небес величезні щелепи страхітливого космічного чудовиська та поглинають останню людину грішної Землі. Апокаліпсис! Чи Армагеддон. Обирайте, що кому до вподоби!

Щасливий випадок, на який режисер натрапив у спортивному магазині? Так. А хіба не всі відкриття народжуються з випадків? Як і життя. Хіба воно не є випадком? Збігом обставин? Як і цей мій опус. Тож хай живе Його Величність Випадок!

В архівах київських театрів мені не пощастило знайти постановок французького шедевру «Собор Паризької Богоматері». Ніхто з режисерів (а були ж і видатні) не наважився на підйом цієї надважкої штанги. А для мене ця обставина видається явною провокацією, що породжує в моєму ЕГО сакраментальне: «Якщо не я, то хто?» Може, тому майже всі мої постановки ніколи не мали київської прописки. Саме через це знову сверблять мої руки. Ставити чергову виставу, аби ставити, я не можу. Мені потрібен спортивний, змагальний азарт. Лише в його котлі я закипаю. Але за умов, що драматургічне «паливо» має неодмінно відповідати моїм філософсько-естетичним уподобанням, моїм образно-метафоричним «збоченням».

Отже, «Собор...». Грандіозне полотно! Певен, мої глядачі обізнані зі світовим паризьким шедевром мюзиклу «Нотр дам де Парі», і який їм клопіт до того, що я був розчарований тим французьким шлягером, у якому Квазімодо - не моральний ідеал в образі огидної потвори, а сексуально заклопотаний красень, який готовий віддати життя за ніч з Есмеральдою, а це нанівець знищує головний сенс роману Гюго. Есмеральда паризького мюзиклу теж спантеличує мої сподівання - вона не 16-річне незаймане дитя природи, а надто доросла (м'яко кажучи) жіночка та надто вже (якомога м'якше кажучи), не Джина Лоллобріджида, що остаточно відкидає славнозвісний світовий шедевр на смітник літератури, де тліють сценарії попсових мильних опер. Париж запропонував попсі (хай вибачать мені за щирість) типовий зразок ринкової маскультури, добряче сколочений та загорнутий у красивий фантик. Мені більш до впо- доби дотепна думка австрійського композитора Арнольда Шьонберга: «Якщо ие мистецтво, значить, це не для всіх; а якщо це для всіх, значить, ие не мистеитво».

Однак розчарування паризьким шлягером лише підлило олії у вогонь, і мене охопив величезний спортивний азарт! Виявляється, з Парижем можна змагатись! Але не їх зброєю з багатомільйонним бюджетом, а своєю, метафоричною, яка нічого не коштує, окрім безсонних ночей. Отже, до Бою!

То ж чим будемо брати? Не втомлююсь повторювати студентам режисерських кафедр та слухачам майстер-класів, що в сучасному театрі мистецька цінність вистави твориться не тоннами металу, не кубометрами дров на сцені та не кілометрами коштовних тканин i не солідним бюджетом, а мізками режисера та сценографа, які винахідливою образною лексикою здатні здійняти сценічний твір на таку височінь, звідки всі ці тонни, кубометри та кілометри здаватимуться жалюгідним хламом. Цю аксіому усьому світові блискуче демонстрували і Пітер Брук, і Сжи Гротовський, і Юрій Любимов, і Еймунтас Някрошюс (далі можете продовжити за власною ерудицією), а нині - нове покоління авангардної європейської режисури, хоча й перебуває воно вже у присмерках славнозвісної Золотої Ери.

Вочевидь, будувати на сцені Собор Паризької Богоматері ми не будемо, хоча й більшість подій відбувається саме в ньому та біля нього. В пошуках образного рішення сценічного простору поставимо перед собою запитання: Що $є$ духовною серцевиною твору Гюго? Чим він потрясає? Хто є його головним героєм? Есмеральда? В жодному разі! Красивих героїнь в літературі - море. А от аналогів Квазімодо не знайдемо ніде. Він уособлює духовний ідеал Людини, максимально наближеної до ідеалу божественного, тому позбавлений автором роману гріховних статевих ознак. Таким його створив Гюго і виграв любов людства. На противагу генієві його земляки-парижани забажали іншого сексуально заклопотаного героя-коханця, готового віддати життя лише за одну ніч з коханою. Для цього вони створили «Нот Дам де Парі» і... програли любов людства, але виграли любов попси. Браво! Кесарю, як писано в Свангелії, кесарево, а як кажуть у нас: «Хто на що вчився».

Отже, Квазімодо. Навколо нього й слід будувати цю історію, запропонувавши суспільству в наші смутні часи ідеальну модель Людини та людських відносин. Де живе Квазімодо? У дзвіниці собору, служачи в ньому дзвонарем. Немає 
сенсу будувати й дзвіницю. Будь-яке копіювання приводить митця до глухого кута. 3 чим найбільше контактує Квазімодо? 3 канатами дзвонів. От і звісимо зі штанкетів канати додолу на всю височінь дзеркала сцени. Скільки? Мені знадобилось двадцять два пенькових канати. Чорний оксамит і ліс канатів.

До речі, доля Есмеральди перегукується з долею Мауглі - вона виросла в лісових хащах, серед розбійників. Отже ліс канатів - це і їі природне середовище.

Нарешті, середньовічний Париж був театром масових страт під овації публіки. Натуральних страт. На кожній площі - по шибениці. Отже, кінці кожного канату піднімаємо на півтора метри та закріплюємо карабінами на канаті й отримуємо зашморг для повішення. От вам і ліс шибениць. Цими канатами ми вже вбили трьох зайців - вони $\epsilon$ знаряддям праці Квазімодо-дзвонаря, природним середовищем Есмеральди та середньовічним Парижем 3 численними шибеницями, на яких $\mathrm{i}$ має завершити своє життя наша красуня.

Канатний ліс подарував нам універсальну систему, що надала можливість шляхом певних композиційних комбінацій на очах у публіки творити безліч образів місця дії та самої дії - музику дзвонів, судові засідання, тюремні грати, тортури підвішеного на канатах Квазімодо, постіль-гамак для інтимної зустрічі Есмеральди з Фебом, гойдалки, польоти мух, келію-схованку для Есмеральди, ешафот, i, нарешті, сцену страти Есмеральди.

Опишу деякі образні сцени, пов'язані 3 канатами.

В променях світла бачимо рій мух, що літають під звуки власного дзижчання. Це актори, «запряжені» в петлі канатів, розкинувши руки-крила, «літають» у просторі сцени. 3'являється архідиякон Клод, який за романом у виставі полює на Есмеральду, розставляючи їй, немов павук, всіляке павутиння. 3 появою священика наростає звук рою.

КЛОД. Ти літаєш, ти тріумфуєш. Ти тільки що народилася. Ти жадаєш весни, вільного повітря, свободи! Але варто тобі наштовхнутися на павутину, як до тебе підповзає огидний павук.
(Чуємо звуки мушачого рою та бачимо, як він у виконанні акторів-мух б'ється в агонії). 3 відірваними крилами ти б'єшся в залізних лапах долі, але павук пожирає тебе (рій завмирає).

Якби тобі навіть і вдалося прорвати цю небезпечну павутину своїми мушачими крильцями, то невже ти сподіваєшся, що виберешся до світла? Як здолати тобі скло (бачимо та чуємо, як мухи-актори пластичними засобами б'ються об скло), цю прозору перешкоду, непохитну, як скеля? Скільки мудреців розбиваються об неї на смерть! Скільки людських доль стикаються i дзижчать на цьому вічному склі? (Мухи замертво падають на підлогу).

Судове засідання над Есмеральдою:

Високо над залом засідання сидить гігантський Суддя в чорних окулярах (у Гюго він глухий, а у нас він і глухий, і сліпий). Величезна пурпурна суддівська мантія розкинулась по всьому простору сцени. По боках - підвішені на канатах, як на гаках у м'ясній крамничці тушки, покалічені жертви судочинства. По центру авансцени Есмеральда, пов'язана канатами, що тягнуться вгору до Судді. В залі суду - свідки та нерозлучна подруга Есмеральди - Коза (маріонеткова лялька).

Після завершення допиту Кози та Есмеральди Суддя урочисто проголошує промову-вирок. Раптом нерви Кози не витримують і вона починає бігати по залу, за нею кидається в погоню охорона, зчиняється загальний галас, Раптом Коза стрибає вгору на Суддю та під загальний вереск присутніх здирає 3 нього мантію. Настає тиша, всі ошелешені виглядом Судді: без мантії - це лише голе, худе та мале тільце. Без мундира відкрилась його нікчемна суть. А ми хіба не за мундиром сприймаємо людину? Як бачите, шановні читачі, для викриття антинародної сутності суддівської системи ми застосували два сценічних тропи: Суддю від гіперболи скинули у літоту (або антигіперболу) і отримали вражаючий образно-філософський прийом, який творить узагальнену соціальну історію на противагу французькій, сексуальній. А який шлях мистецьки багатший, змістовніший - судити Всевишньому. 